\title{
The Institutional Factor and Chinese Direct Investment in Developing Countries
}

\author{
Han Jiaqi \\ School of Economics \\ Shanghai University \\ Shanghai, China \\ never925@126.com
}

\begin{abstract}
This paper investigated the impact of institutional environment of the host country and the gap of institution between the host country and China on China's outward foreign investment by positivist research based on the Chinese direct investment in developing countries of 2003-2013, and following are some conclusions drown from the study: (1) Chinese outward foreign investment are inclined to the developing countries whose institutional environment is poor and has large differences from China, showing the "special" side of Chinese OFDI; (2) Chinese OFDI has obvious market motivation, market seeking motivation OFDI tend to choose areas whose institutional environment is poor, and the system quality of host country has negative influence on Chinese resource seeking motivation OFDI.
\end{abstract}

Keywords-OFDI; developing countries; institutional environment; institutional gap; institutional factors

\section{INTRODUCTION}

With the development of China's economic, China's foreign direct investment has a substantial increase. In 2003, the net foreign direct investment of China was 2.85 billion dollars, and this data has been more than 107.84 billion dollars in 2014, with an average annual growth rate of $43.8 \%$, and China has become one of the important capital-exporting countries. By the end of 2013, China's total net foreign investment (stock) amounted to 660.48 billion US dollars, investment destination include not only the developed countries, but also the majority of the developing countries. Since 2003, more than eighty percent of China's OFDI every year flow into the developing countries. In 2013, Chinese FDI stock of developing countries reached 458.81 billion dollars, accounting for 86.3 percent of China's foreign total investment. This shows that developing countries have become a major destination for China's OFDI.

Location choice is the most important part of multinational investment, which is related to the size of the risk of the company's future operations and success (Dunning, 1). Traditional theories of international investment have made abundant achievements, and now some scholars have begun to study on geographical distribution of OFDI from institutional soft environment. New institutional economics think that the business environment will affect the international competitiveness of enterprises, and the institutional factors of host country will directly affect the effectiveness of multinational strategic decisions of enterprises. In the study of multinational direct investment, legal perspective has been the emphases of research on FDI from the perspective of institutional factors, however, the existing studies do not deepen this research form the public and private system, and not take the impact of institutional gap between the host country and China into account. Most studies related to the institutional factors took the developed countries as the research object, seldom took the developing countries as the main body of the study, and the FDI theories do not necessarily apply to China because there are obvious differences between the developed countries and China in ownership and business, so this article tries to take the developing countries whose institutional environments are close to China as the study subject, and explore the impact of institutional factors of developing countries on China's OFDI, and solve the following two questions: (1) what is the impact of institutional environment of developing countries on China's OFDI; (2) what is the impact of the institutional gap between the developing countries and China on China's OFDI.

\section{THEORY AND HYPOTHESIS}

\section{A. The influence of host country institutional environment on China's OFDI}

The institution environment is the foundation of one country's economic and social development. It is the framework of the interaction between individuals, companies, government and other major players through the public system and private institution, which is related to the profit distribution, development strategies and investment decisions(Economic Forum World, 2). The government's attitude to the market and the operate efficiency of the host countries have a significant impact on the multinational Corporation's investment decisions, bureaucracy and formalism, excessive regulation, corruption, the political judicial system can lead to a large amount of economic cost shared by multinational companies, consequently hinder the inflow of foreign capital. As a business manager, how do deal with the relationship between government and other enterprises and the public, how to prevent fraud and perfect management, how to maintain the confidence of investors and consumers, these will affect the confidence of foreign investors.

Dunning(3) pointed out that the whole institution environment of developed countries is better than others, it can provide a relatively stable business environment and effective protection for foreign investors, so that investors can make effective investment strategies, this is what is absent in developing country with relatively poor institution environment. In the areas where have weak 
market, the role of institution factors is very important (McMillan, 4). Blonigen (5) asserted that the lack of perfect institution environment would increase the possibility of the loss of property of foreign investors, and then lead to a higher investment cost. Globerman (6) believed that the judicial system, supervision and government efficiency and other public goods' quality would lower the expected return of investors, and hinder the foreign capital inflows. But some scholars have found that the quality of the system of the host countries has a negative impact to the scale of investment of China. Countries with smaller gap in system are more familiar with each other's market environment and trading rules. The ownership and business environment of China are much different from the developed countries. Chinese companies can use the non-market behavior to get markups because of developing countries' imperfect market and poor market supervision, invalid law enforcement, thus have a higher environmental adaptability and anti-risk ability. This comparative advantage makes the China's market-seeking OFDI can choose the region which have similar institution environment with China and even the countries which lag behind with china to invest.

Kolstad (7) holded that China's investment in developing countries has the obvious motivation of seeking resources. The state-owned enterprises in China can be supported by many policies such as soft budget, low interest loans, special protection system, that hence the certain ownership advantages and strong anti-risk ability of Chinese enterprises. On contrast, the average size of non-SOE enterprises is much smaller and can't get much resources support from government, consequently, their investments abroad are limited by institutional factors. State-owned enterprises' investments in foreign countries is deemed to seek resources, making China's resource-seeking OFDI turn to developing countries, which institution environment is relatively poor. Above all, we put forward the first hypothesis.

Hypothesis 1: The institutional environment of developing countries has a negative effect on the OFDI from china.

\section{B. The influence of the institutional gap on China's OFDI}

Due to the national economic development level, different systems between nations will be present variety forms. Easterly (8) pointed out that the institutional differences could explain the most causes of the differentiation between countries. The absolute differences of institution between the host country and China would influence the scale of foreign capital inflows. Habib and Zurawicki (9) suggested that the countries with similar system have less learning cost for similar trading rules and institutional environment. Kolstad (7) found that Chinese companies are more inclined to choose developing country with small institutional gap to invest. Buckley(10) found Chinese companies tend to use "non-market behavior" and "bribe behavior" to exploit opportunities in the market of host country, and that make Chinese multinational enterprise have more advantages in international competition with the developed countries.

The above researches often put developed countries as the main body, it is not clear whether the traditional theory is fit to China. Some domestic scholars found that China's company prefer the countries and regions with big institutional gap. The developing countries with poor institutional environment tend to have larger defect legal, and it lower the economic and moral cost of Chinese enterprises to make use rent-seeking activities to obtain investment opportunities(Yeung $\mathrm{H}$ W\&Liu W,11). In conclusion, we put forward the hypothesis 2.

Hypothesis 2: China's FDI for developing countries prefer the areas whose institutional environment.

\section{EMPIRICAL TEST}

\section{A. Research methods}

In the paper, we use the investment gravity model and select fixed effects model of panel data to have regression analysis. We set institutional environment (INS), institutional gap(INSD) as the dependent variables, set the GDP and GPD growth rate of host countries as the control variables, and set China's OFDI to each member of the chosen 58 countries as independent variables. The empirical model is as follows:

$$
\begin{aligned}
& \ln F D I_{\mathrm{it}}=c+\beta_{1} \ln G D P_{i(\mathrm{t}-1)}+\beta_{2} \ln P G D P_{i(\mathrm{t}-1)}+\beta_{3} G G D P_{i(\mathrm{t}-1)}+\beta_{4} O P E_{i(\mathrm{t}-1)} \\
& +\beta_{5} R E S_{i(\mathrm{t}-1)}+\beta_{6} I N F_{i(\mathrm{t}-\mathrm{l})}+\beta_{7} M A C_{i(\mathrm{t}-\mathrm{l})}+\beta_{8} \ln D I S_{i(\mathrm{t}-1)}+\sum_{k} \theta^{k} X_{i(\mathrm{t}-\mathrm{l})}^{k}+\varepsilon_{i \mathrm{t}}
\end{aligned}
$$

In the empirical model, $\mathrm{i}$ represents east country, and $\mathrm{t}$ represents observation period, $\varepsilon_{\text {it }}$ represents random perturbed variables. $\beta$ represents the coefficient of dependent variables .

\section{B. Data Source}

This paper selects China's direct investment in developing countries of 2003-2013 as the research object, and chose 58 developing countries which have close economic ties with China, the FDI data are collected from the China's foreign direct investment statistical bulletin.

The institutional environment data are from "global competitiveness report" released by the World Economic Forum every year. With the reference of Habib and

Zurawwici(8)'s study, the institutional gap will be measured by the absolute value of the institutional environment difference between the two countries. The other variables like distance(DIS), GDP of host countries, GPD growth rate(HGDP), trade openness(OPE), infrastructure(INF), resources(RES), macroeconomic environment(MAC) are collected from World Development Indicators.

\section{Emprical Results}


TABLE I . THE REGRESSION RESULT

\begin{tabular}{|c|c|c|c|c|c|c|c|}
\hline variable & 1 & 2 & 3 & 4 & 5 & 6 & 7 \\
\hline lngdp & $\begin{array}{l}3.482 * \\
(1.60)\end{array}$ & $\begin{array}{c}3.459^{* *} \\
(1.60)\end{array}$ & $\begin{array}{c}3.445^{* *} \\
(1.61)\end{array}$ & $\begin{array}{c}6.040^{* *} \\
(1.93)\end{array}$ & $\begin{array}{c}3.465^{* *} \\
(1.61)\end{array}$ & $\begin{array}{c}3.413^{* *} \\
(1.68)\end{array}$ & $\begin{array}{c}3.345^{* * *} \\
(1.63)\end{array}$ \\
\hline Inpgdp & $\begin{array}{l}-1.681 \\
(1.74)\end{array}$ & $\begin{array}{l}-1.620 \\
(1.75)\end{array}$ & $\begin{array}{l}-1.592 \\
(1.76)\end{array}$ & $\begin{array}{l}-2.799 \\
(1.79)\end{array}$ & $\begin{array}{l}-1.608 \\
(1.71)\end{array}$ & $\begin{array}{l}-1.628 \\
(1.75)\end{array}$ & $\begin{array}{l}-1.450 \\
(1.85)\end{array}$ \\
\hline ggdp & $\begin{array}{c}0.0488^{*} \\
(0.02)\end{array}$ & $\begin{array}{c}0.0492^{* *} * \\
(0.02)\end{array}$ & $\begin{array}{c}0.0494 * * \\
(0.02)\end{array}$ & $\begin{array}{c}0.0452 * * \\
(0.02)\end{array}$ & $\begin{array}{c}0.0495^{* *} \\
(0.03)\end{array}$ & $\begin{array}{c}0.0481^{* *} * \\
(0.09)\end{array}$ & $\begin{array}{c}0.0505^{* *} \\
(0.03)\end{array}$ \\
\hline ope & $\begin{array}{c}0.0802^{*} \\
(0.98)\end{array}$ & $\begin{array}{c}0.0765^{* *} \\
(0.97)\end{array}$ & $\begin{array}{c}0.0785^{* * *} \\
(0.98)\end{array}$ & $\begin{array}{c}0.0289 * * \\
(0.99)\end{array}$ & $\begin{array}{c}0.0061^{* *} \\
(0.97)\end{array}$ & $\begin{array}{c}0.0756^{* * *} \\
(0.98)\end{array}$ & $\begin{array}{c}0.0724 * * \\
(0.98)\end{array}$ \\
\hline res & $\begin{array}{c}0.188^{* *} \\
(0.11)\end{array}$ & $\begin{array}{c}0.0186^{* * *} \\
(0.11)\end{array}$ & $\begin{array}{c}0.0184^{*} \\
(0.13)\end{array}$ & $\begin{array}{c}0.0211^{*} \\
(0.15)\end{array}$ & $\begin{array}{l}0.187 \\
(0.17)\end{array}$ & $\begin{array}{c}0.0325^{*} \\
(0.37)\end{array}$ & $\begin{array}{l}0.0212 \\
(0.33)\end{array}$ \\
\hline Inf & $\begin{array}{c}0.548^{* *} * \\
(0.20)\end{array}$ & $\begin{array}{l}0.326^{*} \\
(0.19)\end{array}$ & $\begin{array}{c}0.524 * * \\
(0.20)\end{array}$ & $\begin{array}{l}0.316 \\
(0.27)\end{array}$ & $\begin{array}{c}0.325^{*} \\
(0.19)\end{array}$ & $\begin{array}{c}0.557 * * * \\
(0.27)\end{array}$ & $\begin{array}{l}0.329 * \\
(0.19)\end{array}$ \\
\hline mac & $\begin{array}{c}0.207 * * \\
(0.17) \\
\end{array}$ & $\begin{array}{c}0.199^{* *} * \\
(0.17) \\
\end{array}$ & $\begin{array}{c}0.199 * * \\
(0.17) \\
\end{array}$ & $\begin{array}{c}0.237 * * \\
(0.14)\end{array}$ & $\begin{array}{c}0.199 * * \\
(0.16)\end{array}$ & $\begin{array}{c}0.215^{* * *} \\
(0.21)\end{array}$ & $\begin{array}{c}0.187 * * \\
(0.19)\end{array}$ \\
\hline Indis & $\begin{array}{c}-6.605^{*} \\
(3.52) \\
\end{array}$ & $\begin{array}{c}-6.528^{*} \\
(3.56)\end{array}$ & $\begin{array}{c}-6.643^{*} \\
(3.55) \\
\end{array}$ & $\begin{array}{c}-7.084 * * \\
(3.76)\end{array}$ & $\begin{array}{c}-6.541^{*} \\
(3.55)\end{array}$ & $\begin{array}{c}-7.632 * * \\
(3.68)\end{array}$ & $\begin{array}{c}-6.541 * \\
(3.77) \\
\end{array}$ \\
\hline Ins & $\begin{array}{c}0.810^{* * *} \\
(0.30)\end{array}$ & & $\begin{array}{c}-0.744^{*} \\
(0.31)\end{array}$ & $\begin{array}{c}-1.61 * * \\
(5.04)\end{array}$ & & $\begin{array}{c}-0.503 * \\
(0.42)\end{array}$ & \\
\hline Insd & & $\begin{array}{l}0.350^{*} \\
(0.24)\end{array}$ & $\begin{array}{c}0.0877 * \\
(0.24)\end{array}$ & & $\begin{array}{c}0.418 * * \\
(3.69)\end{array}$ & & $\begin{array}{c}0.309 \\
(0.311)\end{array}$ \\
\hline Ins*gdp & & & & $\begin{array}{c}-0.463^{* *} \\
(0.98)\end{array}$ & & & \\
\hline Insd*gdp & & & & & $\begin{array}{c}-0.0199^{*} \\
(0.42)\end{array}$ & & \\
\hline Ins*res & & & & & & $\begin{array}{c}-0.0792 * * \\
(0.67)\end{array}$ & \\
\hline Insd*res & & & & & & & $\begin{array}{c}0.0138 \\
(0.0691)\end{array}$ \\
\hline $\mathrm{R}^{\wedge} 2$ & 0.7086 & 0.7446 & 0.7268 & 0.7225 & 0.7341 & 0.7541 & 0.7152 \\
\hline
\end{tabular}

\section{EMPIRICAL ANALYSIS}

Model 1 examines the influence of institutional environment in developing countries on the size of Chinese OFDI, there is significantly inverse relationship between the institutional environment in host country and the scale of China's OFDI. This conclusion confirms the hypothesis 1 that locational distribution of Chinese OFDI has its own characteristics that China's OFDI tend to invest in the host country whose institutional environment is worse. The explanations are likely to be the following: Firstly, the competitiveness of Chinese enterprises is weaker than that of developed countries, Chinese companies tend to invest in developing countries whose system environment is relatively poorer and the areas have not been took up by the multinational companies of Europe and the United States; Secondly, the developing countries set a low threshold for Chinese capital, technology, management, mid-range capacity to "walk in", who also have a huge potential consumer market for China; Thirdly, incompletely domestic market, unsound legal system and poor regulation make it possible for Chinese companies to use "non-market behavior" and establish a "network" in the developing countries with poor institutional environment, which will bring convenience for business operation and gain a competitive advantage in turn for Chinese companies.

Habib and Zurawicki (8) pointed out that the absolute difference of system between the host country and home country significantly influences OFDI inflows. We introduce the variable of the institutional gap between developing countries and China in model 2 to examine its impact on China's OFDI. As you can see, the gap between two different system is significantly positive under the $10 \%$ level, it implies that the greater institutional differences between the two countries, the more conducive to attract China's OFDI to enter. This conclusion supports the hypothesis two, but it reacts against the "institutional theory", showing that China's FDI outward to developing countries offends against the traditional theory. In order to improve the influence of institutional factors in developing countries on China's OFDI, we set up the model 3 to introduce the institutional environment and gap at the same time, as you can see, both of them keep significant under $10 \%$ level, it indicates that China's OFDI tends to enter developing countries or regions whose institutional environment is relatively poor and institutional gap with China is relatively large. 
In the models above, the coefficients of GDP and GDP growth rate of host country are significantly positive under $5 \%$ level, it illustrates that Chinese OFDI flowing into developing countries has obvious market seeking motivation, the greater the size of the market of host country is, the greater the market potential will be, and then the easier it is to attract Chinese OFDI, that result is consistent with traditional OFDI theory. The per capita GDP of host country can reflect a country's market opportunity or pay level, the negative coefficient in the model shows that Chinese investment to developing countries attempts to reduce costs--- efficiency seeking OFDI, but the influence of market opportunities in developing countries or regions on efficiency seeking OFDI of China is not obvious.

For further research about the influence of institutional environment in the host country on Chinese OFDI about different motivation, model 4 introduces a cross terms of the institutional environment and GDP of host country on the basis of model 1 . The result shows that the estimated coefficients of cross terms is significantly negative under the $5 \%$ level, it indicates that there is a strong interaction between them---- market seeking OFDI of China tends to choose developing countries and regions whose institutional environment are relatively poor. Model 5 introduces a cross terms of institutional gap and the host country's GDP on the basis of model 2, we can see the estimated coefficient of the cross terms is significantly negative under the $10 \%$ level, it indicates that the greater the difference of system between China and the host country, the greater the scale of China's OFDI inward to host country. In most developing countries, the industry foundation, electrical design, equipment manufacturing, engineering implementation, maintenance and operation management are still very weak, which offer a good opportunities for Chinese enterprises to export products and investment in infrastructure, equipment and technology. That makes it possible that market seeking OFDI of China enters developing countries whose institutional environment is relatively "bad".

Then we set up model 6 and 7 to test the effect of the institutional environment of host country and institutional gap on resources seeking OFDI of China. The regression results show that interaction coefficient of the institutional environment and resources endowment in the host country is significantly negative, but the gap of the two different system is not significant, which indicates that developing countries or regions with relatively poor institutional environment attract more resource seeking OFDI of China. The phenomenon of corruption, rent-seeking in some developing countries with rich resources bring uncertainty to foreign investors, but resource seeking enterprises of China have "ownership advantages" and "non-market incentives", they could tolerate ever greater risk, compared with multinational corporations in developed countries. And then China's enterprises could choose the countries and regions with poor institutional environment but rich resource, such as Africa and Latin America.

\section{CONCLUSIONS}

This paper investigated the impact of institutional environment of the host country and the gap of institution between the host country and China on Chinese outward foreign investment by positivist research, and we found that Chinese outward foreign investment are inclined to the developing countries whose institutional environment is poor and has large differences from China, showing the "special" side of Chinese OFDI. Chinese enterprises should fully consider the institutional risk of developing countries and promote economic cooperation with developing countries through trade, investment and other international cooperation. The Chinese government and enterprises should take "One Belt And One Road" and the establishment of the investment bank as an opportunity to actively carry out international cooperation and industrial connection, tap the potential for cooperation and strengthen the complementary advantages with developing countries, and optimize the pattern of China's opening to the outside world.

\section{REFERENCES}

[1] ]Dunning J H. Location and the Multinational Enterprise: A Neglected Factor?[J]. Journal of International Business Studies, 1998, volume 40(1):45-66.

[2] World Economic Forum, The Global Competitiveness Report 2009-2010[M]. Geneva: SRO-Kundig, 2009, P4.

[3] Dunning J H, Lundan S M. Multinational enterprises and the global economy[M]. Edward Elgar Publishing, 2008.

[4] McMillan D. Structural breaks in financial ratios: evidence for nine international markets[J]. Applied Financial Economics Letters, 2007, volume 3(6):381-384.

[5] Blonigen B A. 2005. A Review of the Empirical Literature on FDI Determinants[J]. Atlantic Economic Journal, 2005, 33(4):383-403.

[6] Globerman S. Foreign direct investment and'spillover'efficiency benefits in Canadian manufacturing industries[J]. Canadian journal of economics, 1979: 42-56.

[7] Wiig A, Kolstad I. Multinational corporations and host country institutions: A case study of CSR activities in Angola[J]. International business review, 2010, 19(2): 178-190.

[8] Easterly W. National policies and economic growth: a reappraisal[J]. Handbook of economic growth, 2005, 1: 1015-1059.

[9] Habib M, Zurawicki L. Corruption and Foreign Direct Investment[J]. General Information, 2002, volume 33(2):291-307.

[10] Buckley P J, Cross A R, Tan H, et al. Historic and emergent trends in Chinese outward direct investment.[J]. Management International Review, 2008, 48(6):715-748.

[11] Yeung H W, Liu W. Globalizing China: The Rise of Mainland Chinese Firms in the Global Economy[J]. Eurasian Geography \& Economics, 2008, 49 